\title{
ANALISIS KANDUNGAN NITRIT DALAM SOSIS PADA DISTRIBUTOR SOSIS DI KOTA YOGYAKARTA TAHUN 2011
}

\author{
Hasna Hayati Nur, Dyah Suryani \\ Fakultas Kesehatan Masyarakat, Universitas Ahmad Dahlan Yogyakarta
}

\begin{abstract}
Background: Sausage was a snack with raw meat, crushed meat preserved by salting. Nitrate and nitrite salt is one of the preservatives used in meat preservation process to obtain good color and prevent microbial growth. Nitrite as a preservative permitted its use, but keep in mind its use in food in order not to exceed the limits, so it does not negatively impact human health. Permenkes Republic of. 1168/Menkes/Per/X/1999 about food additives limit the maximum use of the preservative nitrite in processed meat product that is equal to $125 \mathrm{mg} / \mathrm{kg}$. Excessive consumption of nitrite can cause harm to the wearer, whether they are direct, ie poisoning, or who are indirect, ie nitrites are carcinogenic. The purpose of this study to determine the content of nitrite in sausages at sausage distributor in the city of Yogyakarta in 2011.

Method: The study was descriptive research laboratory test. The object of this study were 5 brand sausage sausage found in a different distributor. Nitrite content analysis conducted by two stages of testing, the test qualitative and quantitative test. Qualitative test performed to determine whether there is content of nitrite in sausages by using reagents sulfanilat acid- $\alpha$ naftilamina, while the quantitative tests conducted to determine the levels of nitrite contained in the sausage with a spectrophotometer. Data analysis results of research done descriptively and are presented in table and narrative.

Results: The study of five brands of sausage on the distributor in the city of Yogyakarta shows that all brands of sausage samples containing nitrite with nitrite levels varied.

Conclusion: Of the 5 brands of sausage samples studied, the results showed that one sample had higher levels of nitrite that does not meet the requirements under Decree No. Permenkes. $1168 /$ Menkes $/ \mathrm{Per} / \mathrm{X} / 1999$, namely the brand sausage sample $\mathrm{E}$ with higher levels of nitrite of $211.294 \mathrm{mg} / \mathrm{kg}$.
\end{abstract}

Keywords: Analysis, sausage, nitrite

\section{PENDAHULUAN}

Semakin meningkatnya jumlah penduduk, maka kebutuhan makanan juga akan semakin meningkat. Peningkatan kebutuhan akan makanan dapat dipenuhi dengan dilakukannya penambahan zat kimia pada makanan yang dikenal sebagai zat tambahan makanan. ${ }^{1}$

Bahan Tambahan Makanan (food additive) adalah bahan yang biasanya tidak digunakan sebagai makanan dan biasanya bukan merupakan komponen khas makanan, mempunyai atau tidak mempunyai nilai gizi, yang dengan sengaja ditambahkan ke dalam makanan untuk maksud teknologi pada pembuatan, pengolahan, penyiapan, perlakuan, pengepakan, pengemasan dan penyimpanan. ${ }^{2}$ Zat tambahan makanan berarti bahan apa pun yang biasanya tidak dimakan sendiri sebagai suatu makanan dan biasanya tidak digunakan sebagai bahan-bahan khas untuk makanan, baik mempunyai nilai gizi atau tidak, yang bila ditambahkan dengan sengaja pada makanan untuk tujuan teknologi diharapkan berakibat (secara langsung atau tidak langsung) makanan itu atau hasil sampingannya menjadi bagian komponen makanan itu atau mempengaruhi ciri-ciri makanan itu. 
Istilah ini tidak mencakup "pencemar" atau zat-zat yang ditambahkan pada makanan untuk mempertahankan atau memperbaiki mutu gizi. ${ }^{1}$

Beberapa zat kimia ditambahkan pada makanan untuk meningkatkan keawetannya, untuk membuat makanan itu dapat diproduksi secara missal atau untuk meningkatkan daya tarik bagi konsumennya dalam segi warna, rasa, bentuk dan kemudahan. ${ }^{1}$ Bahan tambahan sangat membantu proses pengolahan makanan selama kadarnya tidak melebihi kadar yang dapat ditolerir oleh tubuh. ${ }^{3}$

Saat ini, industri makanan telah berkembang demikian pesat dengan proses pengolahan yang sangat maju. Bahkan dalam rumah tangga pun telah menggunakan bahan-bahan tambahan. Zaman dahulu, hasil produksi suatu makanan hanya dapat dijual di dalam lingkungan yang sangat terbatas, tetapi sekarang sudah memungkinkan diedarkan ke seluruh dunia. Bahan tambahan tersebut dapat berupa bahan pengawet, bahan pemanis buatan, penyedap rasa dan bahan pewarna. ${ }^{3}$

Sejak pertengahan abad ke-20 ini, peranan bahan tambahan pangan (BTP) khususnya bahan pengawet menjadi semakin penting sejalan dengan kemajuan teknologi produksi bahan tambahan pangan sintesis. Banyaknya bahan tambahan pangan dalam bentuk murni dan tersedia secara komersil dengan harga yang relatif murah akan mendorong meningkatnya pemakaian bahan tambahan pangan berarti meningkatkan konsumsi bahan tersebut bagi setiap individu. ${ }^{4}$

Daging termasuk makanan yang mengandung protein. Protein merupakan salah satu makanan yang penting bagi tubuh, mempunyai fungsi sebagai pertumbuhan sel, pengganti sel yang rusak dan sebagai bahan bakar dalam tubuh manusia. Oleh sebab itu kekurangan protein dapat menyebabkan gangguan pada manusia. Daging mudah rusak, untuk penyimpanan yang lama dibutuhkan bahan pengawet. Nitrat dan nitrit merupakan salah satu zat pengawet yang digunakan dalam proses pengawetan daging untuk memperoleh warna yang baik dan mencegah pertumbuhan mikroba. Nitrit sebagai pengawet diijinkan penggunaannya, akan tetapi perlu diperhatikan penggunaannya dalam makanan agar tidak melampaui batas, sehingga tidak berdampak negatif terhadap kesehatan manusia. Permenkes RI No. 1168/Menkes/Per/X/1999 ${ }^{2}$ tentang bahan tambahan makanan, membatasi penggunaan maksimum pengawet nitrit di dalam produk daging olahan yaitu sebesar $125 \mathrm{mg} / \mathrm{kg}$. Konsumsi nitrit yang berlebihan dapat menimbulkan kerugian bagi pemakainya, baik yang bersifat langsung, yaitu keracunan, maupun yang bersifat tidak langsung, yaitu nitrit bersifat karsinogenik. ${ }^{4}$

Era globalisasi sekarang ini, banyak masyarakat yang menginginkan sesuatu secara instan, sebagai contoh makanan siap saji. Makanan siap saji yang saat ini digemari masyarakat adalah sosis. Sosis merupakan produk olahan daging yang mempunyai nilai gizi tinggi, berbentuk silindris dengan panjang kira-kira $8 \mathrm{~cm}-$ $10 \mathrm{~cm}$ yang tidak hanya digemari anak-anak, melainkan remaja dan dewasa bahkan orang tua juga menyukai sosis.

Berdasarkan hasil pengamatan di lapangan pada bulan Maret 2011, tempura merupakan salah satu jajanan yang paling digemari anak-anak usia SD (Sekolah Dasar), khususnya di Kota Yogyakarta, hampir di setiap sekolah dasar terdapat penjual tempura. Penjual tempura juga ditemukan di tempat-tempat strategis seperti alun-alun, namun ada beberapa yang berjualan keliling desa dan ada yang membuka warung tempura di rumah. Selain tempura, penjual juga menjajakan sosis sebagai salah satu dagangannya. Maraknya konsumen yang mengkonsumsi sosis mendorong produsen sosis untuk memperoleh keuntungan sebesar-besarnya dengan biaya sekecil-kecilnya yaitu dengan menambahkan nitrit pada daging olahan. Penggunaan nitrit dilakukan untuk meminimalisir ketengikan yang dapat muncul pada daging dan dapat memperpanjang masa simpan produk daging. Hal ini dikarenakan produk sosis tidak selalu habis terjual hanya dalam 
waktu satu hari, penyimpanannya pun dilakukan pada suhu beku yaitu disimpan di freezer.

Ketengikan pada sosis dapat diminimalisir, seperti pada 9 penjual tempura di Kecamatan Umbulharjo yang hanya membeli 2 sampai 3 bungkus sosis per hari, sedangkan 6 penjual tempura di Alun-Alun Kidul mengambil sosis sesaat sebelum mereka berjualan, hal ini dilakukan karena tidak semua penjual tempura mempunyai freezer dan sosis hanya mampu bertahan paling lama dua hari di luar freezer. Penjual tempura mendapatkan sosis dari distributor yang berbeda, yaitu distributor Alun-Alun Kidul, Pasar Kranggan, Kotagede dan Timoho. Target utama konsumen sosis adalah anak-anak sekolah dasar pada khususnya dan masyarakat pada umumnya. Tujuh dari sepuluh siswa menyatakan kesukaan mereka terhadap jajanan ini, dari rasanya yang enak, bentuk dan namanya yang unik. Pada umumnya, siswa-siswa tersebut hanya melihat tampilan dan rasa dari sosis itu sendiri tanpa mengetahui atau bahkan memerhatikan dampak negatif dan bahaya kandungan zat pengawet yang terdapat pada sosis. Oleh karena itu, peneliti ingin menganalisis kandungan nitrit dalam sosis pada distributor sosis di Kota Yogyakarta.

\section{METODE PENELITIAN}

Jenis penelitian ini adalah penelitian deskriptif dengan uji laboratorium. Subjek pada penelitian ini adalah distributor sosis di Kota Yogyakarta dan objek penelitian adalah 5 merk sosis yang terdapat pada distributor sosis yang berbeda. Penelitian ini dilakukan di Laboratorium CV. Chem-Mix Bantul Yogyakarta pada tanggal $15-18$ Mei 2011.

\section{A. Alat dan Bahan}

1) Pengambilan sampel

Alat yang digunakan dalam pengambilan dan pengiriman sampel adalah kantong plastik sebagai pembungkus sosis dan kertas label untuk memberi tanda pada masing-masing merk sosis

2) Pemeriksaan sampel

a) Uji Kualitatif

1. Alat
a) Timbangan
b) Tabung reaksi
c) Gelas ukur
d) Mortir
e) Stamper
f) Centrifuge

2. Bahan
a) Sosis
b) Larutan Kalium alumunium sulfat
c) Larutan asam sulfanilat
d) Larutan N-1-naftiletilen-diamonium diklorida
e) Aquadest

b) Uji Kuantitatif

1. Alat

a) Spektrofotometer 

b) Timbangan
c) Vortex
d) Cawan
e) Gelas ukur $100 \mathrm{ml}, 500 \mathrm{ml}$
f) Labu Erlenmeyer $50 \mathrm{ml}$
g) Pipet volumetri $10 \mathrm{ml}, 25 \mathrm{ml}$
h) Kertas saring

2. Bahan
a) Sosis
b) Natrium nitrit
c) Larutan kalium aluminium sulfat
d) Larutan asam sulfanilat
e) Larutan N-1-naftiletilen-diamonium diklorida
f) Aquadest

\section{B. Cara Kerja}

1) Pengambilan sampel

2) Pemeriksaan atau uji nitrit di laboratorium

a) Uji kualitatif

Masing-masing sampel merk sosis ditimbang sejumlah 5 gram kemudian diletakkan di mortir, dihaluskan homogen dengan ditambahkan aquadest $25 \mathrm{ml}$. Sampel yang sudah dihaluskan kemudian dimasukkan ke dalam tabung reaksi, masing-masing ditambahkan larutan kalium alumunium sulfat $\left(\mathrm{KASO}_{4}\right) \quad 20 \%$ dan dimasukkan ke dalam centrifuge selama 10 menit. $\mathrm{KASO}_{4}$ berfungsi untuk memisahkan larutan protein (mengendap) dan larutan bening (kemungkinan mengandung nitrit). Larutan bening dari masing-masing sampel diambil dengan pipet dan di masukkan ke dalam tabung reaksi, kemudian masing-masing ditambahkan $1 \mathrm{ml}$ larutan asam sulfanilat $\%, 1 \mathrm{ml} \alpha$ diphenyl amin $0,1 \%$ dan $1 \mathrm{ml} \mathrm{N}$-1-naftiletilen-diamonium diklorida, diamati perubahan warna yang terjadi, perubahan warna larutan dari bening menjadi merah muda menunjukkan bahwa larutan tersebut mengandung nitrit.

b) Uji kuantitatif

Larutan uji:

Masing-masing sampel merk sosis ditimbang sejumlah 5 gram kemudian diletakkan di mortir, dihaluskan homogen dengan ditambahkan aquadest $25 \mathrm{ml}$. Sampel yang sudah dihaluskan kemudian dimasukkan ke dalam tabung reaksi, masing-masing ditambahkan larutan kalium alumunium sulfat $\left(\mathrm{KASO}_{4}\right) 20 \%$ dan dimasukkan ke dalam centrifuge selama 10 menit. Larutan bening dari masing-masing sampel diambil dengan pipet dan di masukkan ke dalam tabung reaksi, kemudian masing-masing ditambahkan $1 \mathrm{ml}$ larutan asam sulfanilat \%, 1 $\mathrm{ml}$ a diphenyl amin $0,1 \%$ dan $1 \mathrm{ml} \mathrm{N}$-1-naftiletilen-diamonium diklorida, dikocok.

Larutan baku:

Sejumlah $42 \mathrm{mg}$ natrium nitrit yang ditimbang, dimasukkan ke dalam gelas ukur $500 \mathrm{ml}$, ditambah $100 \mathrm{ml}$ aquadest dan dikocok. Masingmasing larutan standar dencerkan menjadi $1 \mathrm{ml}$ dan ditambah $1 \mathrm{ml}$ larutan asam sulfanilat $1 \%$ dan $1 \mathrm{ml} \alpha$ diphenyl amin $0,1 \%$. Kemudian diencerkan dengan aquadest menjadi $10 \mathrm{ml}$. 
Larutan blangko:

Sejumlah $1 \mathrm{ml}$ larutan asam sulfaninat $1 \%$ dan $1 \mathrm{ml}$ larutan $\mathrm{N}-1$ naftiletilen diamonium diklorida, dimasukkan ke dalam gelas ukur $100 \mathrm{ml}$ dan ditambah aquadest.

Cara penetapan:

Serapan larutan A dan B diukur dengan spektrofotometer, panjang gelombang maksimum lebih kurang $520 \mathrm{~nm}$ larutan blangko. ${ }^{5}$

Perhitungan: Kadar Nitrit $=\frac{X \times \text { Faktor Pengenceran }}{\text { Berat Sampel }} \times 1000$

X $\quad$ : absorbansi (serapan) $-a b$

Faktor pengenceran : $\frac{25}{1} \mathrm{ml}$

Berat sampel : gram

Kadar nitrit $\quad: \mathrm{mg} / \mathrm{kg}$

c) Mencatat hasil uji laboratorium

\section{Analisis Data}

Analisis data dilakukan secara deskriptif yaitu kandungan nitrit hasil pemeriksaan di laboratorium dibuat dalam bentuk tabel dan dinarasikan.

\section{HASIL PENELITIAN DAN PEMBAHASAN}

\section{A. Hasil Penelitian}

Penelitian ini dilaksanakan di wilayah Kota Yogyakarta tahun 2011, jumlah sampel yang diteliti sebanyak 5 merk sosis yang terdiri dari 3 merk sosis daging ayam yaitu merk $A, C$ dan $D$ serta 2 merk sosis daging sapi yaitu merk $B$ dan E. Sampel diambil dari distributor yang berbeda yang terletak di Kota Yogyakarta dan kemudian diperiksa di laboratorium CV. Chem-Mix Pratama Bantul. Pemeriksaan nitrit dilakukan dengan reagensia asam sulfanilat- $\alpha-$ naftilamina (uji Griess-llosvay) sebagai uji kualitatif, yaitu untuk mengetahui ada tidaknya kandungan nitrit dalam sosis dan metode spektrofotometri UV sebagai uji kuantitatif, yaitu untuk mengetahui kadar nitrit dalam sosis. Hasil perhitungan kadar nitrit diperoleh dalam bentuk $\mathrm{mg} / \mathrm{kg}$ kemudian hasilnya disesuaikan dengan Permenkes RI No. 1168/Menkes/Per/X/1999² tentang Bahan Tambahan Makanan (BTM), yang membatasi penggunaan maksimum pengawet nitrit di dalam produk daging olahan yaitu sebesar $125 \mathrm{mg} / \mathrm{kg}$ dan melihat penggunaan pengawet nitrit dalam sosis sudah memenuhi baku mutu untuk dikonsumsi oleh masyarakat. 
1) Kandungan Nitrit dalam Sosis Pada Distributor Sosis di Kota Yogyakarta Tahun 2011

Tabel 1. Kandungan Nitrit dalam Sosis Pada Distributor Sosis di Kota Yogyakarta Tahun 2011

\begin{tabular}{|c|c|c|c|c|c|}
\hline No. & Mer & osis & Warna Mula-mula & Warna Akhir & Keterangan \\
\hline \multirow{2}{*}{1} & \multirow{2}{*}{ A } & A1 & Bening & Merah muda & + \\
\hline & & A2 & Bening & Merah muda & + \\
\hline \multirow{2}{*}{2} & \multirow{2}{*}{ B } & B1 & Bening & Merah muda & + \\
\hline & & B2 & Bening & Merah muda & + \\
\hline \multirow{2}{*}{3} & \multirow{2}{*}{ C } & C1 & Bening & Merah muda & + \\
\hline & & $\mathrm{C} 2$ & Bening & Merah muda & + \\
\hline \multirow{2}{*}{4} & \multirow{2}{*}{ D } & D1 & Bening & Merah muda & + \\
\hline & & $\mathrm{D} 2$ & Bening & Merah muda & + \\
\hline \multirow{2}{*}{5} & \multirow{2}{*}{$\mathrm{E}$} & E1 & Bening & Merah muda & + \\
\hline & & E2 & Bening & Merah muda & + \\
\hline
\end{tabular}

Keterangan:
A, C, D : sosis daging ayam
$\mathrm{B}, \mathrm{E} \quad$ : sosis daging sapi
1 : percobaan pertama
$2 \quad$ : percobaan kedua
$+\quad$ : mengandung nitrit
- $\quad$ : tidak mengandung nitrit

Berdasarkan tabel 1 dapat diketahui bahwa semua sampel merk sosis, baik sosis daging ayam maupun sosis daging sapi mengandung nitrit yang ditunjukkan dengan perubahan warna bening menjadi merah muda, sehingga dapat dilanjutkan dengan uji kuantitatif untuk mengetahui kadar nitrit dalam sosis tersebut.

2) Kadar Nitrit dalam Sosis Pada Distributor Sosis di Kota Yogyakarta Tahun 2011

Tabel 2. Kadar Nitrit dalam Sosis Pada Distributor Sosis di Kota Yogyakarta Tahun 2011

\begin{tabular}{|c|c|c|c|}
\hline No. & \multicolumn{2}{|c|}{ Merk Sosis } & Kadar Nitrit (mg/kg) \\
\hline \multirow{2}{*}{1} & \multirow{2}{*}{ A } & A1 & 90,309 \\
\hline & & A2 & 91,249 \\
\hline \multirow{2}{*}{2} & \multirow{2}{*}{ B } & B1 & 86,495 \\
\hline & & B2 & 84,748 \\
\hline \multirow{2}{*}{3} & \multirow{2}{*}{ C } & C1 & 85,073 \\
\hline & & $\mathrm{C} 2$ & 83,354 \\
\hline \multirow{2}{*}{4} & \multirow{2}{*}{ D } & D1 & 101,812 \\
\hline & & D2 & 100,990 \\
\hline \multirow{2}{*}{5} & \multirow{2}{*}{$\mathrm{E}$} & E1 & 211,294 \\
\hline & & E2 & 205,105 \\
\hline
\end{tabular}

Pada tabel 2 dapat diketahui bahwa kelima sampel merk sosis yang diteliti mengandung nitrit dengan kadar nitrit yang bervariasi, yaitu pada percobaan pertama, kadar nitrit pada merk sosis A sebesar $90,309 \mathrm{mg} / \mathrm{kg}$, B sebesar $86,495 \mathrm{mg} / \mathrm{kg}$, C sebesar $85,073 \mathrm{mg} / \mathrm{kg}$, D sebesar $101,812 \mathrm{mg} / \mathrm{kg}$ dan merk sosis E sebesar $211,294 \mathrm{mg} / \mathrm{kg}$. Pada percobaan kedua, kadar 
nitrit merk sosis A sebesar $91,249 \mathrm{mg} / \mathrm{kg}$, B sebesar $84,748 \mathrm{mg} / \mathrm{kg}$, C sebesar $83,354 \mathrm{mg} / \mathrm{kg}$, D sebesar $100,990 \mathrm{mg} / \mathrm{kg}$ dan merk sosis $\mathrm{E}$ sebesar 205,105. Kadar nitrit tertinggi tardapat pada merk sosis E yaitu sebesar $211,294 \mathrm{mg} / \mathrm{kg}$ dan kadar terendah terdapat pada merk sosis C yaitu sebesar $83,354 \mathrm{mg} / \mathrm{kg}$.

3) Kesesuaian Kadar Nitrit dalam Sosis Pada Distributor Sosis di Kota Yogyakarta Tahun 2011 dengan Baku Mutu Menurut Permenkes RI No. 1168/Men/Per/1999

Tabel 3. Kesesuaian Kadar Nitrit dalam Sosis Pada Distributor Sosis di Kota Yogyakarta Tahun 2011 dengan Baku Mutu Menurut Permenkes RI No. 1168/Men/Per/1999

\begin{tabular}{|c|c|c|c|c|}
\hline No. & \multicolumn{2}{|c|}{ Merk Sosis } & Kadar Nitrit (mg/kg) & $\begin{array}{c}\text { Baku Mutu Kadar Nitrit } \\
\text { Menurut Permenkes RI } \\
\text { No 1168/Men/Per/1999 } \\
(\mathrm{mg} / \mathrm{kg})\end{array}$ \\
\hline \multirow{2}{*}{1} & \multirow{2}{*}{ A } & A1 & 90,309 & \multirow{10}{*}{125} \\
\hline & & A2 & 91,249 & \\
\hline \multirow{2}{*}{2} & \multirow{2}{*}{ B } & B1 & 86,495 & \\
\hline & & B2 & 84,748 & \\
\hline \multirow{2}{*}{3} & \multirow{2}{*}{ C } & C1 & 85,073 & \\
\hline & & $\mathrm{C} 2$ & 83,354 & \\
\hline \multirow{2}{*}{4} & \multirow{2}{*}{ D } & D1 & 101,812 & \\
\hline & & D2 & 100,990 & \\
\hline \multirow{2}{*}{5} & \multirow{2}{*}{ E } & E1 & 211,294 & \\
\hline & & E2 & 205,105 & \\
\hline
\end{tabular}

Hasil penelitian dari dua kali percobaan menunjukkan bahwa kadar nitrit pada merk sosis $A, B, C$ dan $D$ masih berada di bawah baku mutu menurut Permenkes RI No 1168/Men/Per/1999 yaitu di bawah 125 mg/kg, sedangkan kadar nitrit pada merk sosis $\mathrm{E}$ melebihi baku mutu menurut Permenkes RI No 1168/Men/Per/1999 yaitu sebesar 211,294 mg/kg.

\section{B. Pembahasan}

Jumlah sampel yang diteliti pada penelitian ini sebanyak 5 merk sosis yang terdiri dari 3 merk sosis daging ayam yaitu merk $A, C$ dan $D$ serta 2 merk sosis daging sapi yaitu merk B dan E. Sampel diambil dari distributor yang berbeda yang terletak di Kota Yogyakarta. Pengambilan sampel dilakukan pada pagi sampai siang hari kemudian sampel dibawa ke laboratorium Chem-Mix Bantul untuk diteliti kandungan dan kadar nitrit di dalamnya.

Berdasarkan hasil uji kualitatif kandungan nitrit dalam sosis dapat diketahui bahwa semua sampel merk sosis yang diteliti mengandung nitrit, sedangkan kadar nitrit yang terdapat dalam 5 sampel merk sosis tersebut bervariasi. Kadar nitrit tertinggi tardapat pada merk sosis $\mathrm{E}$ yaitu sebesar $211,294 \mathrm{mg} / \mathrm{kg}$ dan kadar terendah terdapat pada merk sosis $C$ yaitu sebesar $83,354 \mathrm{mg} / \mathrm{kg}$.

Hasil penelitian ini menunjukkan bahwa kadar nitrit pada sampel merk E melebihi batas maksimum penggunaan nitrit pada produk olahan daging menurut Permenkes RI No 1168/Men/Per/1999 yaitu memiliki kadar sebesar $211,294 \mathrm{mg} / \mathrm{kg}$. Walaupun kadar nitrit beberapa sampel sosis yang diteliti masih 
berada di bawah batas maksimum menurut Permenkes RI No. 1168/Menkes/ Per/X/1999², yaitu $125 \mathrm{mg} / \mathrm{kg}$, namun konsumsi sosis yang mengandung nitrit yang beredar di pasaran tetap perlu diperhatikan karena nitrit bersifat kumulatif dalam tubuh manusia.

Kadar nitrit hasil pemeriksaan pada masing-masing sampel menunjukkan perbedaan yang cukup besar, hal ini dapat terjadi karena adanya perbedaan lama penyimpanan dari setiap sampel sehingga ada faktor yang dapat mempengaruhi kadar nitrit pada setiap sampel. Faktor tersebut adalah telah terjadinya reaksi nitrosasi dalam produk daging, yaitu terbentuknya nitrosamin dari interaksi antara nitrit dan amin sekunder atau tersier. Semakin lama penyimpanan bahan-bahan yang mengandung nitrit dan amin, akan meningkatkan pembentukan nitrosamin. ${ }^{6}$

Pada penelitian ini setiap sampel diambil dari distributor berbeda dan asal sosis juga berbeda. Sampel merk A, B dan C merupakan olahan industri rumah tangga, sedangkan sampel sosis merk $D$ dan $E$ berasal dari olahan pabrik. Dari hasil terselubung yang dilakukan oleh peneliti, sebagian besar penjual tempura yang menjajakan dagangannya di sekolah-sekolah dasar menggunakan sampel sosis merk $\mathrm{E}$. Alasan penjual menggunakan merk tersebut karena murah, enak dan mudah didapat. Hal ini perlu mendapatkan perhatian khusus dari BPOM dan Depkes terkait dengan hasil penelitian ini yang menunjukkan bahwa kadar nitrit pada sampel merk sosis $E$ melebihi baku mutu menurut Permenkes RI No. 1168/Menkes/Per/X/1999. ${ }^{2}$

Berdasarkan pengamatan yang dilakukan terhadap masing-masing sampel merk sosis, diketahui bahwa semua merk sosis tersebut telah memperoleh ijin Depkes dan dinyatakan aman untuk dikonsumsi. Namun pada kenyataannya, ada sampel merk sosis yang pada labelnya tidak mencantumkan adanya bahan pengawet nitrit, bahkan ada yang mencantumkan tulisan dengan huruf kapital bahwa sosis tersebut tanpa bahan pengawet, sedangkan pada hasil penelitian ini didapat bahwa semua sampel merk sosis mengandung nitrit. Hal ini merupakan salah satu bentuk pelanggaran terhadap Peraturan Menteri Kesehatan RI No. 79/Menkes/Per/III/1978 tentang Label dan Periklanan Makanan. Pada label produk makanan harus mencantumkan antara lain: nama makanan atau merk dagang, komposisi, nama dan alamat perusahaan, nomor pendaftaran dan kode produksi.

Penggunaan nitrit dilakukan untuk meminimalisir ketengikan yang dapat muncul pada daging dan dapat memperpanjang masa simpan produk daging. Hal ini dikarenakan produk sosis tidak selalu habis terjual hanya dalam waktu satu hari, penyimpanannya pun dilakukan pada suhu beku yaitu disimpan di freezer. Perbedaan lama penyimpanan produk sosis, khususnya penyimpanan di distributor sosis dapat terjadi karena masing-masing produsen sosis tidak mengirimkan produk sosis dalam waktu yang bersamaan. Sebagian produsen sosis mengirimkan produk sosis ke distributor sosis tiga hari sekali, bahkan ada yang mengirimnya dua minggu sekali tergantung permintaan distributor. Penyimpanan produk sosis ada yang mencapai enam bulan tergantung dari kualitas produk sosis tersebut. Semakin baik kualitas produk sosis, maka penyimpanannya semakin lama. Contohnya produk sosis yang harganya mahal dan terkenal, biasanya dijual di swalayan besar seperti Progo dan Gardena.

Konsumsi nitrit yang berlebihan dapat menimbulkan kerugian bagi pemakainya, baik yang bersifat langsung, yaitu keracunan, maupun yang bersifat tidak langsung, yaitu nitrit bersifat karsinogenik. Apabila nitrit yang terkonsumsi jumlahnya banyak, maka NO yang terbentuk juga banyak. NO yang terserap dalam darah, mengubah haemoglobin darah manusia menjadi nitrose haemoglobin atau methaemoglobin yang tidak berdaya lagi mengangkut 
oksigen. Kebanyakan penderita methaemoglobinemia menjadi pucat, cianosis (kulit kebiru-biruan), akibatnya sesak nafas, muntah dan shock. Kematian pada penderita dapat terjadi apabila kandungan methaemoglobin lebih tinggi dari \pm $70 \% .^{8}$

Nitrat dari sumber makanan yang tertelan akan diserap di usus kecil dan akan bercampur dengan nitrat dari endogenouse jalur NO. Nitrat yang beredar akhirnya diekskresikan dalam urin, sebanyak $25 \%$ secara aktif diekstraksi oleh kelenjar ludah dan terkonsentrasi dalam air liur. Di mulut, bakteri anaerob fakultatif mengurangi nitrat menjadi nitrit oleh aksi enzim reduktase nitrat. Pengurangan bakteri nitrat menjadi nitrit telah mendapat perhatian karena nitrit didapat dari nitrosamin yang berpotensi karsinogenik. ${ }^{9}$ Oleh sebab itu perlu ditetapkan batas penggunaan harian (daily intake) bahan kimia. Konsep Acceptable Daily Intake (ADI) didasarkan pada kenyataan bahwa semua bahan kimia yang digunakan sebagai bahan pengawet adalah racun, tetapi toksisitasnya sangat ditentukan oleh jumlah yang diperlukan untuk menghasilkan pengaruh atau gangguan kesehatan atau sakit. ${ }^{4} \mathrm{ADI}$ didefinisikan sebagai besarnya asupan harian zat kimia yang bila dikonsumsi seumur hidup, tampaknya tanpa risiko berarti berdasarkan semua fakta yang diketahui pada saat itu. ADI dinyatakan dalam miligram zat kimia per kilogram berat badan $(\mathrm{mg} / \mathrm{kg}){ }^{1}$ Untuk keamanan, konsumsi nitrit pada manusia dibatasi sampai 0,4 $\mathrm{mg} / \mathrm{kg}$ berat badan per hari. ${ }^{8}$

Hasil penelitian yang dilakukan oleh Cory ${ }^{10}$ di Kota Medan menunjukkan bahwa 3 dari 10 sampel daging burger yang diteliti, yaitu pada kode sampel $\mathrm{BI}$, CII dan Ell memiliki kadar nitrit yang tidak memenuhi syarat kesehatan menurut Permenkes No. 1168/Menkes/Per/X/19992. Kadar nitrit pada kode sampel BI sebesar $128 \mathrm{mg} / \mathrm{kg}$, Cll sebesar 135,2 mg/kg dan pada kode sampel Ell sebesar $160 \mathrm{mg} / \mathrm{kg}$. Purbanugraha ${ }^{11}$ melakukan penelitian di Kota Yogyakarta dengan sampel dendeng sapi berlabel dan non label yang didapatkan hasil bahwa kadar nitrit dari 10 sampel yang diteliti masih berada dibawah kadar nitrit maksimum menurut Permenkes No. 1168/Menkes/Per/X/19992, yaitu kadar nitrit tertinggi $104,7 \mathrm{mg} / \mathrm{kg}$ pada sampel no. 4 (dendeng sapi non label), sedangkan kadar nitrit terendah sebesar $14,9 \mathrm{mg} / \mathrm{kg}$ pada sampel no. E (dendeng sapi berlabel).

Husni, dkk ${ }^{12}$ melaporkan hasil penelitian mengenai analisa zat pengawet dan protein dalam makanan siap saji sosis yang dilakukan di Kota Padang, Sumatera Barat, menunjukkan hasil bahwa dari ketiga sampel yang diuji dengan metode reaksi warna mengandung nitrit dan nitrat sebagai pengawet, walaupun produk tersebut tidak mencantumkan adanya pengawet pada komposisi produk.

Besarnya kadar nitrit dalam produk daging olahan merupakan faktor penghambat pertumbuhan bakteri Clostridium botulinum. Akan tetapi besarnya kadar nitrit juga berhubungan dengan pembentukan nitrosamin yang bersifat karsinogenik. Senyawa nitrosamin dapat terbentuk dengan mudah dari interaksi antara nitrit dan amin sekunder atau tersier, terutama pada kondisi asam. Hal tersebut diperkuat dengan penelitian seorang ahli yang mempelajari pembentukan nitrosodietilamin (NDEA) dari dietilamin dan nitrit dalam lambung manusia, kelinci, kucing, anjing dan tikus. Pembentukan NDEA ternyata lebih cepat dalam cairan lambung manusia dan kelinci $(\mathrm{pH} 1-2)$ dibandingkan dengan dalam cairan lambung tikus $(\mathrm{pH} 4-5) .{ }^{6}$ Salah satu kelebihan nitrosamin dibandingkan dengan karsinogenik lainnya adalah kapasitasnya untuk menimbulkan tumor pada bermacam-macam organ. ${ }^{4}$ Organ tersebut antara hati, ginjal, kandung kemih, lambung, kerongkongan dan sistem syaraf pusat. ${ }^{6}$ Nitrosamin adalah mutagen serta karsinogen yang menyebabkan kanker di 
berbagai organ termasuk hati, saluran pernafasan, ginjal, saluran kencing, kerongkongan, perut, saluran bawah pencernaan dan pankreas. ${ }^{13}$

Ginjal merupakan alat ekskresi penting yang mempunyai 3 fungsi, yaitu filtrasi, absorbsi dan reabsorbsi. Proses tersebut berhubungan dengan pembentukan urin. Tiga kelas zat yang difiltrasi dalam glomerulus yaitu elektrolit, nonelektrolit dan air. $\mathrm{NO}_{2}$ termasuk golongan natrium yang merupakan zat elektrolit. $\mathrm{NO}_{2}$ akan diabsorbsi dan kemudian melewati tahapan reabsorbsi, sedikitnya dua pertiga jumlah natrium yang difiltrasi akan direabsorbsi di dalam tubulus proksimal. Sebagian natrium ada yang keluar bersama urin dan sebagian ada yang tertinggal. Natrium dalam hal ini $\mathrm{NO}_{2}$ yang tertinggal lama kelamaan akan menumpuk di dalam ginjal dan dapat memperberat kerja ginjal, sehingga akan merusak organ ginjal yang menyebabkan ginjal tidak dapat berfungsi sebagaimana mestinya. Untuk selanjutnya $\mathrm{NO}_{2}$ akan dimetabolisme di dalam hati. Hati berfungsi untuk penetral racun, apabila kerja organ hati terganggu atau rusak akibat semakin banyaknya racun yang tidak dapat dimetabolisme, maka $\mathrm{NO}_{2}$ tersebut akan menumpuk dan dapat menyebabkan kanker hati. ${ }^{14}$

Saat ini belum ditemukan bahan kimia lain yang dapat menggantikan fungsi nitrit pada proses curing daging olahan. Oleh sebab itu, jalan yang dapat ditempuh untuk mencegah terbentuknya senyawa nitrosamin adalah dengan mengurangi kadar nitrit dalam produk daging olahan tetapi tetap menjaga agar bakteri Clostridium botulinum tidak tumbuh. Caranya antara lain dengan mengurangi jumlah nitrit yang digunakan sebagai bahan pengawet disertai dengan penambahan bahan anti-mikroba seperti sorbat atau menambahkan vitamin $\mathrm{C}$ atau vitamin $\mathrm{E}$ ke dalam daging olahan yang merupakan penghambat reaksi nitrosasi. ${ }^{6}$

Tanpa nitrit didalam produk daging olahan, risiko Clostridium botulinum akan meningkat. Kombinasi pemakaian nitrit dan asam askorbat serta penyimpanan pada temperatur dingin kira-kira $3^{\circ} \mathrm{C}$ akan memperpanjang masa simpan produk daging olahan, seperti daging kornet sapi dan sosis daging sapi. Penggunaan bahan tambahan lain dalam proses curing juga dapat memperpanjang masa simpan produk daging olahan. Bahan tambahan tersebut antara lain gula, penyedap dan bumbu, garam dan merica, bahan pemanis, bahan pengisi, bahan pengikat atau pengompak, bahan extender serta zat padat susu kering tanpa lemak. ${ }^{15}$

Produsen sosis di Indonesia sepertinya lebih memilih alternatif untuk menggunakan vitamin $\mathrm{C}$ atau vitamin $\mathrm{E}$ untuk mengurangi kadar nitrit dalam sosis. Hal tersebut ditunjukkan dalam beberapa label merk sosis yang diteliti telah mencantumkan adanya vitamin $C$ didalamnya. Walaupun tidak semua produk yang diteliti menambahkan vitamin $\mathrm{C}$ ke dalam sosis, namun kadar nitrit mereka tidak jauh berbeda seperti yang terlihat pada hasil penelitian. Meskipun demikian perlu diwaspadai kandungan nitrosamin antara produk sosis yang menambahkan vitamin $\mathrm{C}$ dan yang tidak menambahkan vitamin $\mathrm{C}$, karena nitrosamin akan mudah terbentuk apabila vitamin $C$ sebagai penghambat reaksi tidak ditambahkan ke dalam produk sosis tersebut, sehingga memungkinkan kadarnya lebih tinggi. ${ }^{6}$ Penggunaan pengawet nitrit pada produk sosis tidak dapat diketahui ciri-ciri khusus yang dapat dilihat langsung dengan mata, maka masyarakat harus lebih hati-hati dalam membeli atau mengkonsumsi sosis. 


\section{SIMPULAN DAN SARAN}

\section{A. Simpulan}

Berdasarkan hasil penelitian mengenai kandungan nitrit dalam sosis pada distributor sosis di Kota Yogyakarta tahun 2011, maka dapat disimpulkan sebagai berikut:

1) Semua sampel merk sosis yang diteliti mengandung nitrit.

2) Kadar nitrit tertinggi tardapat pada merk sosis E yaitu sebesar $211,294 \mathrm{mg} /$ $\mathrm{kg}$ dan kadar terendah terdapat pada merk sosis C yaitu sebesar 83,354 $\mathrm{mg} / \mathrm{kg}$.

3) Kadar nitrit pada merk sosis $A, B, C$ dan $D$ masih berada di bawah baku mutu menurut Permenkes RI No 1168/Menkes/Per/1999 yaitu di bawah 125 $\mathrm{mg} / \mathrm{kg}$, sedangkan kadar nitrit pada merk sosis $\mathrm{E}$ melebihi baku mutu menurut Permenkes RI No 1168/Menkes/Per/1999 yaitu sebesar 211,294 $\mathrm{mg} / \mathrm{kg}$.

\section{B. Saran}

1) BPOM dan Dinas Kesehatan Kota Yogyakarta

Diharapkan untuk menginformasikan peraturan tentang penggunaan bahan tambahan makanan dan bahaya penggunaan bahan makanan tersebut terhadap kesehatan, khususnya pada pengawet nitrit.

2) Fakultas Kesekatan Masyarakat Universitas Ahmad Dahlan

a) Memberikan sosialisasi kepada masyarakat tentang konsumsi nitrit yang aman. Sebenarnya sosis aman dikonsumsi apabila kita bisa mengatur frekuensi dan jumlah yang dimakan. Dalam seminggu kita bisa makan 15 sosis, akan tetapi tidak dibarengi dengan konsumsi daging olahan lain seperti nugget, ham, burger. Sebisa mungkin kurangi konsumsi daging yang berlebihan dan seimbangkan dengan sayuran, minum air putih serta olahraga. Cara aman sebelum mengkonsumsi sosis, sebaiknya terlebih dahulu membaca label pada kemasan mengenai kadar natriumnya dan bandingkan antar berbagai merek. Pilihan sebaiknya jatuh pada sosis yang kadar natriumnya paling rendah.

b) Diperlukan penelitian lebih lanjut tentang analisis kandungan nitrit dengan metode penelitian deskriptif analitik, seperti hubungan perilaku dan pengetahuan produsen sosis terhadap penggunaan nitrit sebagai pengawet daging.

3) Peneliti selanjutnya

Diperlukan penelitian lebih lanjut tentang analisis kandungan nitrit dengan metode penelitian deskriptif analitik, seperti hubungan perilaku dan pengetahuan produsen sosis terhadap penggunaan nitrit sebagai pengawet daging.

\section{DAFTAR PUSTAKA}

1. Lu, F. C., Toksikologi Dasar, Edisi Kedua, Hal. 307-315, UI Press, Jakarta. 1995

2. Departemen Kesehatan RI, Peraturan Menteri Kesehatan Republik Indonesia No. 1168/Menkes/Per/X/1999 Tentang Bahan Tambahan Makanan, Departemen Kesehatan RI, Jakarta. 1999

3. Irianto, K., Waluyo, K., , Gizi dan Pola Hidup Sehat, Hal. 20 dan 75, Yrama Widya, Bandung. 2007 
4. Cahyadi, W., Analisis dan Aspek Kesehatan, Bahan Tambahan Makanan, Edisi kedua, Hal. 1-19, PT Bumi Aksara, Jakarta. 2009

5. Siregar, C.JP., Analisis Bahan Racun Dalam Makanan, Pusat Pemeriksaan Obat dan Makanan, WHO Collaborating Centre For Quality Assurance Of Essential Drugs, Hal. 41-44, Direktorat Jenderal Pengawasan Obat Dan Makanan Departemen Kesehatan RI., Jakarta. 1990

6. Muchtadi, Aspek Biokimia dan Gizi Dalam Keamanan Pangan, Hal. 131-137, Pusat Antar Universitas Pangan dan Gizi Institut Pertanian Bogor, Bogor.1989

7. Departemen Kesehatan RI, Peraturan Menteri Kesehatan RI No. 79/Menkes/Per/ III/1978 tentang Label dan Periklanan Makanan, Departemen Kesehatan RI, Jakarta. 1978

8. Muchtadi, D., Keamanan Pangan, Keracunan Sodium Nitrit: http://web.ipb.ac.id/ حtpg/de/pubde fdsf keracunannitrit.php, diakses pada tanggal 21 September 2010 di Yogyakarta. 2005

9. Lundberg, J. $\mathrm{O}^{1}$., Weitzberg, $\mathrm{E}^{2}$., NO Generation from Inorganic Nitrate and Nitrite: Role Physiology, Nutrition and Therapeutics, Pharmacal Research, ${ }^{1}$ Department of Physiology and Pharmacology, Division of Pharmacology Karolinska Institutet, Stockholm, Sweden, ${ }^{2}$ Department of Physiology and Pharmacology, Division Anesthesiology and Intensive Care Karolinska Institutet, Stockholm, Sweden. 2009

10. Cory, M. S., Analisis Kandungan Nitrit dan Pewarna Merah pada Daging Burger yang Dijual Di Grosir Bahan Baku Burger Di Kota Medan Tahun 2009, Skripsi, Fakultas Kesehatan Masyarakat, Universitas Sumatera Utara, Medan. 2009

11. Purbanugraha, H.S., Kadar Nitrit Dendeng Sapi Berlabel dan Non Label Di Kodia Yogyakarta, Skripsi, Fakultas Kedokteran, Universitas Gadjah Mada, Yogyakarta. 1998

12. Husni, E., Samah, A., Ariati, R., Analisa Zat Pengawet dan Protein, Jurnal Sains dan Teknologi Farmasi, Vol 12, No.2, Hal. 108-111, Fakultas Farmasi, Universitas Andalas Padang, Sumatera Barat. 2007

13. Vries, J., Food Safety and Toxicity, Hal. 23, CRC Press, New York. 1997

14. Neal, M.J., At a Glance Farmakologi Medis, Edisi Kelima, Hal 12-14, Erlangga, Jakarta. 2006

15. Soeparno, IImu dan Teknologi Daging, Hal 1-2 dan 237-241, Gajah Mada University Press, Yogyakarta. 2009 